DOI: $10.2478 / \mathrm{v} 10122-011-0010-9$

\title{
SEMANTICS AND PRAGMATICS OF NON-CANONICAL WORD ORDER IN SOUTH ASIAN LANGUAGES: <VERB-LEFT> OF lag- 'BEGIN' AS AN ATTITUDE-MARKER IN HINDI-URDU'
}

\author{
PETER EDWIN HOOK
}

\begin{abstract}
Peter Edwin Hook. Semantics and Pragmatics of Non-canonical Word Order in South Asian Languages: <Verb-left> of lag- 'begin' as an Attitude-marker in Hindi-Urdu. Lingua Posnaniensis, vol. LIII (2)/2011. The Poznań Society for the Advancement of the Arts and Sciences. PL ISSN 0079-4740, ISBN 978-83-7654-173-0, pp. 25-34.

This paper examines possible motivations for departures from canonical clause-final word order observed for the finite verb in Hindi-Urdu and other modern Indo-Aryan languages. Depiction of speaker attitude in Premchand's novel godān and the imperatives of journalistic style in TV newscasts are shown to be prime factors. The emergence of V-2 word-order in Kashmiri and other Himalayan languages may have had a parallel history.
\end{abstract}

Peter Edwin Hook, Universities of Michigan and Virginia

It is generally recognized that in most South Asian languages the finite verb comes last in its clause:

$$
\begin{aligned}
& \text { jhuniy } \bar{a}^{2} \text { ne gobarkī pịth mẽ halkā.s } \bar{a} \text { ghũus } \bar{a} \text { jamāy } \bar{a} \\
& \text { Jhuniya } \operatorname{Erg}^{3} \text { Gobar's back in light punch delivered } \\
& \text { 'Jhuniya gave Gobar a playful punch in the back.' }
\end{aligned}
$$

Again, as in other South Asian languages, the most common order in formal Hindi-Urdu has complements to the left and the verbs governing them to their right. In colloquial speech, however, we sometimes find instances of what I shall call 'verb-left'; that is, occurrences of

1 This paper, first presented on 22 June 2002 at the 22nd meeting of the South Asian Languages Roundtable at the University of Iowa, has been hibernating since. I am grateful to Krzysztof Stroński for encouraging me to bring it up to date and into print.

2 The transcription system for Hindi and Garhwali is based on one that is in general use in the Indo-Aryan linguistics literature. In it contrastive length in vowels is shown by a macron, nasality in vowels is shown by a tilde, the retroflexion of apical stops and flaps is shown by a sublinear dot and the palatal fricative is represented by an ess with a haček: /š/; the dental affricate of Marathi, by /ts/. Long nasal consonants are represented by doubling the tilded symbol: /ãa , / $\tilde{l} \tilde{u}, / \tilde{u} \tilde{u} /$. The palatalization of consonants in Kashmiri is represented by $/ y /$. This $/ y /$ fronts and raises a following $/ i, \bar{l} /$ and $/ e, \bar{e}$ )/ (which otherwise are high back unrounded and central mid unrounded vowels respectively).

${ }^{3}$ Abbreviations used in this paper include: Abl - ablative, Dat - dative, Emph - emphasis, Erg - ergative, Gen - genitive, Ger - gerund, Hab - habitual, Inf - infinitive, Obl - oblique, PP - postpositional phrase, Pres present tense, Sbjnctv - subjunctive.

${ }^{4}$ The quotations from godān [identified by page and then line number] collate with the 1970 Saraswati Press edition. 
finite verbs somewhere to the left of their complements. The inceptive auxiliary lag 'begin' seems especially likely to occur in this position:

$$
\begin{aligned}
& \text { lage aurõ kī.tarah tum bhī cāplūsì kar-ne } \\
& \text { begun.2plM others like you too flattery do-Inf } \\
& \text { 'There you go, just like the others, trying to flatter me.' }
\end{aligned}
$$

Other verbs, too, in particular those taking oblique infinitival complements, may show 'verb-left';

$$
\begin{aligned}
& \text { ghar-ke parānī rāt-din marẽ aur dāne-dāne-ko tarasẽ, lattāa bhī } \\
& \text { house-'s beings night-day die.Sbjnctv and grain-grain-Dat yearn.Sbjnctv cloth too }
\end{aligned}
$$

pahan-ne-ko mayassar na ho aura ãjulī-bhar rupae le.kar calä hai izzat bacā-ne! put.on-Inf-Dat present not be and hands-full rupees taking set.out is honorsave-Inf

aisī baṛ̂̄ hai terī izzat! jis.ke ghar mẽ cūhe loțẽ, vah bhī izzat-vālā hai! so great is your honor whose house in mice roll he too honor-person is

'His family members suffer day and night and are dying for even a crust to eat. Not a scrap of clothing in the house and off he goes with a fistful of money to preserve his honor! How great your honor is! Mice are frolicking in your house and you're a man of honor!'

(godān 115.30-2)

The conventionally sarcastic presentational expression bara $\bar{a} y \bar{a} V$-ne-vālā discussed in HooK \& JAIN (2002: 369) is also subject to verb-left:

barāa $\bar{a} y \bar{a}$ ghar mẽ rah.ne.vālā!

(McGreGor 1993: 700)

big came house in resider

'He thinks he's a great man (now that he has - or when he is in - his) house!'

Why do speakers place finite forms of lag- 'begin' and other verbs to the left of their complements? In (2), (3), and (4) the speaker is mocking the subject. In (5) the speaker's attitude is explicitly indicated:

$$
\begin{aligned}
& \text { dātādīn cale gae to gobar-ne tiraskār.kī ããkhõ-se dekh-kar kahā } \\
& \text { Datadin moved went then Gobar-Erg contemptuous eyes-with look-ing said }
\end{aligned}
$$

[gaye the devatā-ko manā-ne!]

gone was god-Dat persuade-Inf.Obl

"After Datadin left Gobar said with a look of contempt, "So he'd gone to persuade God!"

In this paper I (A) identify and explore the pragmatic uses of verb-left in Hindi, (B) attempt to determine if there is a statistically valid correlation between verb-left and these pragmatic conditions, (C) look [briefly] at verb-left in headline Hindi, (D) examine verb-left from a typological point of view, and (E) briefly consider how verb-left may be a precursor of the verb's non-clause-final position found in Garhwali, Kochi, Kotgarhi, and other Indo-Aryan languages spoken in the Sub-Himalayan regions to the north and west of Delhi.

A. Is mockery or derision always present in instances of verb-left? In Premchand's godān there are 314 tokens of inceptive lag-. Of these 17 , or a bit over 5\%, come to the left of their complements. ${ }^{5}$ They can be classified under a variety of pragmatic or attitudinal headings.

5 It is striking that over half the instances (9 out of 17) of the verb lag- 'begin' occurring to the left of its infinitival complement come in the first one seventh (50 pages out of 350) of Premchand's novel godān. What 
(6)

$(8 c)$
Mockery or derision:

a. lagā häth jor-ne, pairõ par-ne 50.39

b. aur lag $\bar{a}$ hây-hāy kar-ne 51.2

c. laga hāth jor-ne 51.12

d. lage ghür-ne, chātī pìt-ne 51.32

e. lage aurõ kī tarah tum bhī cāplūsī kar-ne 51.37

f. lage pašto mẽ gāliyãa de-ne 76.13

g. ããdhī kī tarah harharāte hue bāăg mẽ pahũc-kar lage lalkār-ne 269.10

'Howling like a hurricane he reached the garden and began uttering challenges.'

Censure, reproach, reproval:

a. lagte ho kos-ne 8.18

b. lagā apnī gharvā̄i kī burāì kar-ne 22.26

'...began to clasp his hands and fall at (their) feet.' '....and began to clamor and lament.'

'...began to clasp his hands (in supplication)'

See (15)

See (2)

c. aur üpar se lage bhunbhunā-ne 23.7

d. ghasìttā huā alag le jā-kar lagā lātẽ jamā-ne 33.2 ' '...dragged her away and began kicking.'

Depiction of naïveté: The subject is presented as excessively ignorant, rustic, or childish:

a. lagtī püch-ne 29.3

b. lage püch-ne 102.12

c. lage nirakh-ne 308.21

'She would have begun asking...'

'They began to ask...'

'They began to gawk...'

aur lage pūch-ne - kis-ne mārā bāpū? kaise mārā, kahãã mārā,

and began ask-Inf.Obl who-Erg killed "Father" how killed where killed

kaise golī lagī, kahãa lagī, isī ko kyõ lagī, aur hiranõ-ko kyõ na lagī?

how bullet hit where hit this Dat why hit other deer-Dat why not hit

'... and (the children) began peppering them with questions - "Who killed it, Bapu? How did he

kill it? Where did he kill it? How did the bullet hit? Where did it hit? Why did it hit this one?

Why didn't it hit other ones?"”

(godān 102.12)

tab-tak gããv.ke bālakõ-ne ā.kar in donõ ādmiyõ-ko gher liyā

then-by village's children-Erg coming these two men-Dat surround took

aur lage nirakh-ne, mānõ ciriyāa.ghar-ke anokhe jantu $\bar{a}$ gaye hõ.

and began stare-Inf as.if zoo-Gen strange animals come went 3 pl.Sbjnctv

'By then the village children had gathered around both men and begun gaping at them as if two strange animals had come from the zoo.'

(godān 308.21)

Residue: Example (9a) might possibly go with the preceding class or under (7). But there is still need for a "residual" category to accommodate examples like (9b) in which the clausal subject is not [+human], (although the victim of the action described in (9b) is a person whom the narrator disdains.)
a. jhuniya $\bar{l}$ laḡ ghabarāan-ne 122.15
'Jhuniya began to get frightened.'
b. lage do-tarfì kore par-ne (candrakāntā 1.08.054)
'Lashes began to fall right and left.'

On the basis of the evidence found in Premchand's godān the kinds of inceptive situations in which verb-left does not occur include:

might possibly be explanations for this asymmetry? One possibility is that the author used verb-left to characterize the spirited exchanges among the rural characters (Hori, Dhaniya, Gobar, Jhuniya, Rupa, Sona) with whom he clearly had more sympathy than he did with the urban ones (Malati, Mehta, Khanna, Mirza, etc.) who appear later in the novel and are less vividly developed. Or it may be that the later more prosaic style may reflect fatigue and growing pressure on the author to finish. 
Situations or events that do not depend on human will or action:

$\begin{array}{lll}\text { havā-mẽ } & \text { garmī } \bar{a}-n e \quad \operatorname{lag} \overline{\boldsymbol{\imath}} \text { thī } \\ \text { atmosphere-in heat come-Inf begun was }\end{array}$

'Heat had begun to suffuse the air.'

(godān 9.7)

(10b) sārī deh ḍal gaȳ thī ... aur ããkhõ-se bhī kam sūjh-ne lagā thā whole body collapse went was and eyes-with too less appear-Inf began was 'Her whole body had run down ... and her eyesight had begun to worsen.'

(godān 7.29)

Neutral description of situations or events that do depend on human will or action:

gobar-ne baniye-se loțā mããgā aur pānī khĩuc-ne lagā.

Gobar-Erg baniya-from vessel asked.for and waterdraw-Inf began

'Gobar asked the Baniya for his pot and began to draw water.'

(godān 25.34)

Although relevant data are scarce, it seems that clauses whose subjects refer to indefinite or non-specific entities (be they [+human] or [-human]) also do not permit verb-left:

... aur len.dār cārõ taraf-se noc-ne lag.te hã̃

and creditors all.four sides-from snatch-Inf start Pres.3pl

'.... and creditors come out of the woodwork and start grabbing.'

(godān 38.1)

Another condition on verb-left of lag- is that its occurrence seems to be restricted to root or matrix clauses. [See Ross (1973: 408-409) on the "Penthouse Principle".] When lag-occurs in if-clauses or when-clauses it is clause-final:

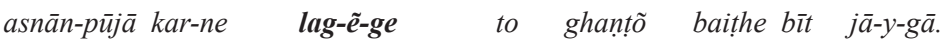

bath-puja perform-Inf begin-3p-Fut.M then hours.Obl sitting pass go-3sg-Fut.M

'Once he starts with his bath and puja I'll have to sit there waiting for hours.'

$(\operatorname{godān} 7.9)$

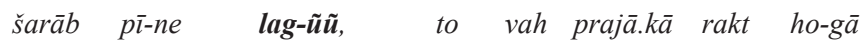

alcohol drink-Inf begin-Sbjnctv then that people's blood be-Fut.M3sg

'If I start drinking, then I am consuming the blood of my subjects.'

(godān 16.5)

B. Is verb-left always used when the speaker wishes to mock or deride? This question must be answered in the negative given pairs like (14) and (15) in each of which lag- has the same predicate as complement and the speaker's attitude seems equally censorious. Still, even though the predicate complements are identical and the situation and speaker's attitude are very similar, (15) has verb-left, while (14) does not:

$$
\begin{aligned}
& \text { isī mare mã̃ kuch pahan-tī-orhh-tī nahĩ. ghar-se niklī } \\
& \text { this.Emph because I something put.on-Hab-pull.on-Hab not house-from went.out }
\end{aligned}
$$

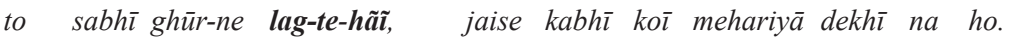

$$
\begin{aligned}
& \text { then all ogle-Inf begin-Hab-Pres as.if ever any woman seen not Sbjnctv } \\
& \text { 'That's why I never put on anything (special). Every time I go out of the house everybody starts } \\
& \text { staring, as if they'd never seen a young woman before.' } \\
& \text { (godān 245.38-9) }
\end{aligned}
$$


na jāne mardõ.kī kyā ādat hai ki jahãã kō̄ javān sundar aurat dekhī not know men's what habit is that where some young beautiful woman saw aur bas lage ghūr-ne, chātī pīt-ne. aur yah jo bare ādmī kahlāte hã̃̃, and that's.it began ogle-ĩnf breast beat-Inf and these who big men be.called are ye to nire lampat hote.hãi. these as.for pure womanizers are

'I don't know what's with these men. Whenever they see some young, pretty woman, that's it! They start staring and beating their chests. And the ones who are held in such high regard, they are womanizers pure and simple!' (godān 51.32-3)

Again, in (16) and (17) the complement of lag- is the same verb kos- 'berate, censure; curse', although it is worth noting that (17) is a direct quote and (16) is not. It is (17) that has verb-left:

jab sab.log apne-apne ghar cale gaye, to dhaniya horī-ko kos-ne lagī-when everyone self's-self's home moved went then Dhaniya Hori-Dat curse-Inf began

tumhẽ kō lākh samjhāye, kar-o-ge apne man-kī

you.Dat someone 100,000 explain.Sbjnct do-2pl-FutMpl self's mind-Gen

'When everyone left for home, Dhaniya began to berate Hori, "No matter how many times you're told, you still go ahead and do what you've taken it into your head to do!"”

(godān 109.8)

dhaniyā-ne tiraskār kiȳa -- acchā rah-ne do, mat asubh müh-se

Dhaniya-Erg contempt did good stay-Inf let Neg inauspicious mouth-from

nikālo. tum-se kō̄ acchī bāt bhī kah-e, to lag-te ho kos-ne bring.out you-to someone good thing too say-Sbjnctv then begin-Hab are curse-Inf

'Dhaniya said scornfully, “Okay, let's forget it. But don't say inauspicious things. Even if a person says something nice to you, you start cussing.",

(godān 8.17-18)

To determine if there is a significant correlation between verb-left and the speaker attitudes listed in (6) through (8) it is necessary to evaluate each member of a sufficiently large random sample of tokens of inceptive lag-. For this purpose I have taken the first 52 instances of V-ne lag- in godān and sorted them into the categories (6) through (8) [censure or reproach, depiction of naïveté, condescension or depiction of naïveté, mockery, or derision] versus categories (10) through (13) [neutral description, inanimate or indefinite subject, if-clause and when-clause]:

Ta b le 1. Tokens of lag- 'begin' in first fifty pages of godān. [See Appendix for full dataset.]

\begin{tabular}{|c|c|c|c|c|}
\hline Type & $<$ lagleft $>$ & Example & \begin{tabular}{|l|} 
(address in \\
Appendix)
\end{tabular} & Number \\
\hline \multirow{2}{*}{ Mockery or derision } & yes & lag $\bar{a}$ häth jor-ne... & $(2 \mathrm{w})$ & 5 \\
\hline & no & sir zamīn par ragar-kar kah-ne lagā: & $(2 x)$ & 1 \\
\hline \multirow{2}{*}{ Censure, reproach, reproval } & yes & lagte ho kos-ne & (1c) & 3 \\
\hline & no & to phir naxre baghār-ne lage & (1q) & 4 \\
\hline \multirow{2}{*}{ Depiction of naïveté } & yes & lagtī pūch-ne, kisak̄̄ gāy hai? & $(1 \mathrm{p})$ & 1 \\
\hline & no & aur uchal-uchal-kar yahī rat lagā-ne laḡ̄ & $(1 \mathrm{k})$ & 2 \\
\hline if-clause & no & šarāb pi-ne lagũũu, to vo prajā kā rakt hogā & (1f) & 5 \\
\hline when-clause & no & ... jab ham ākāsh mẽ ur-ne lagte hã̃ & $(2 \mathrm{~g})$ & 3 \\
\hline \multirow{2}{*}{ Inanimate or indefinite subject } & yes & [none] & & 0 \\
\hline & no & havā mẽ garmī à-ne lagī thī. & (1d) & 8 \\
\hline \multirow{2}{*}{ Neutral description or question } & yes & [none] & & 0 \\
\hline & no & gobar use cakit netrõ se dekh-ne lag $\bar{a}$ & $(2 q)$ & 20 \\
\hline \multicolumn{4}{|c|}{10} & 52 \\
\hline
\end{tabular}


Distributing these fifty-two examples into a tetrachoric table that crosses [+verbleft] and [-verbleft] with [+mockery, censure, naïveté] versus [neutral attitudes] and applying the chi-squares test we find:

Ta b le 2. Consolidated tokens of lag- 'begin' in the first fifty pages of godān

\begin{tabular}{|l|c|c|}
\hline & mockery, etc. & neutral attitudes \\
\hline$[+$ verbleft $]$ & a. 9 & b. 0 \\
\hline$[$-verbleft $]$ & c. 7 & d. 36 \\
\hline
\end{tabular}

$$
X^{2}=\frac{(a d-b c)(a d-b c)(a+b+c+d)}{(a+b)(c+d)(a+c)(b+d)}=\frac{324 \times 324 \times 52}{9 \times 43 \times 16 \times 36}=\frac{5,458,752}{222,912}=24.49
$$

We conclude that the correlation of verb-left with derisive or censorial attitudes is a robust one even at a significance level of one hundredth of one per cent $(p<0.0001)$. (If $\mathrm{X}^{2}>$ 6.67 , then $\mathrm{p}<.01$ ).

C. Verb-left in headline Hindi. In print and electronic media it is becoming common to use verb-left as a way of creating snappy, attention-grabbing headlines. In them the intent may or may not be ironic:

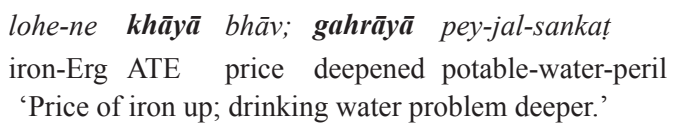

(in.jagran.yahoo.com/news/local/uttarpradesh)

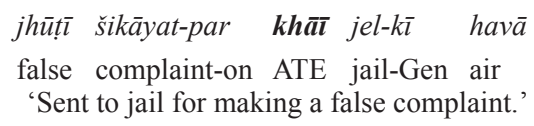

(in.jagran.yahoo.com/news/local/haryana/4_6_4613762.html)

vivek-ne kiȳa kis; $\boldsymbol{k} \boldsymbol{h} \bar{a} . \boldsymbol{y} \overline{\boldsymbol{a}}$ zor.dār cānțtā

Vivek-Erg did kiss ATE powerful slap

'Vivek kissed (her); got slapped hard.'

(thatshindi.oneindia.mobi/movies/bollywood/gossip)

Sometimes the same story contains a non-verb-left paraphrase further down in the report:

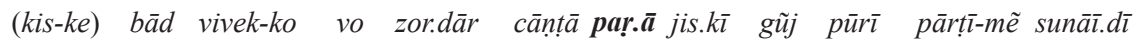
kiss-Gen after Vivek-Dat that powerful slap fell whose echo whole party-in was.heard 'After the kiss he got the slap whose smacking sound was audible to everyone there.' [cf (23)]

D. Typological and morphosyntactic considerations. Leftward placement of the finite verbal element in Hindi-Urdu is not equally easy across all clause-types. For instance, while Hindi inceptives in lag- show the kind of non-canonical order defined by verb-left, permissives in de- 'let' (<de- 'give') do not display it (in godān 0 out of 81 opportunities), even though both govern the oblique form of the infinitive:

$$
\begin{aligned}
& \text { vo apnī qismat kos-ne lagā } \\
& \text { he self's fate curse-Inf began } \\
& \text { 'He began cursing his fate.' }
\end{aligned}
$$

$\left(25^{\prime}\right)$

vo laḡ̄ apnī qismat kos-ne he began self's fate curse-Inf 
use apnī qismat kos-ne do

him self's fate curse-Inf let

'Let him curse his fate.'
(?) use do apnī qismat kos-ne him let self's fate curse-Inf

In (25-25') and (26-26') we see that while the bound morphology on the infinitival complement is the same, yet due either to the semantics or the syntax (or both), the susceptibility to verbleft differs. In (27-27') and (28-28') [from Marathi], although the semantics and syntax are the same, a difference in the bound morphology on the complement affects susceptibility to verb-left: ${ }^{6}$

$$
\begin{aligned}
& \text { to khats-āylā lāglā } \\
& \text { he collapse-Inf.Dat began } \\
& \text { 'He began to lose courage.' }
\end{aligned}
$$

to läglä khats-äylā

he began collapse-Inf.Dat

$$
\begin{aligned}
& \text { to khats-u } \quad \text { lägla } \\
& \text { he collapse-Inf began } \\
& \text { 'He began to lose courage.' }
\end{aligned}
$$

$$
\begin{aligned}
& \text { * to läglā khats-u } \\
& \text { he began collapse-Inf }
\end{aligned}
$$

E. While most South Asian languages have clause-final verb order not all of them have it in root clauses. Exceptions include Khasi (MASICA 1976: 28), Kashmiri, Kochi, Kotgarhi and Garhwali. Kashmiri is V-2:

$$
\begin{array}{lllll}
\text { mye nyuv gari atsān-iy } & \text { èlān } & \text { ker-yith } \\
\text { I.Erg TOOK home.Abl entering-Emph } & \text { announcement } & \text { do-Ger } \\
\text { 'I made an announcement as soon as I entered the house.' } &
\end{array}
$$

(R.L. Shant 1985: p. 61)

Garhwali, Bangani and some other Indo-Aryan languages of Uttarakhand and HP display V-2 tendencies:

$$
\begin{aligned}
& \text { tumhĩ bolā: jhuth chãu mã̃ bol-ṇū? } \\
& \text { you speak false am I } \\
& \text { 'You tell (me): Am I lying?' }
\end{aligned}
$$

(СНАTAк 1976: 122)

Unlike in Hindi-Urdu, in Garhwali we encounter instances of verb-left which are attitudinally neutral:

$$
\begin{aligned}
& \text { silvārāa pākhãũ bi ab ghām.ki najar lhaigi thai jā-na } \\
& \text { damp valleys too now sun's glance begun was go-Inf } \\
& \text { 'Now the sun had begun to peer into damp gullies.' }
\end{aligned}
$$

(NEGI 1967: 2)

In the second half of a misrah from a famous ghazal by Mir we find the finite form of the aspectual auxiliary [aka "vector"] verb $l e$ 'TAKE' in second position with the non-finite element of the verb mũud 'close' stranded at the end, à la root clauses in Kashmiri [cf (29)]:

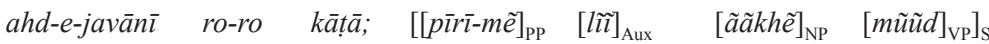

$$
\begin{aligned}
& \text { period-of-youth cry-cry spent old.age-in TOOK eyes close } \\
& \text { 'I passed my youth in agony; when age came I closed my eyes.' }
\end{aligned}
$$

(MIR 1941: 4)

6 Thanks to Madhav Deshpande and Prashant Pardeshi for (identical) acceptability judgments on the Marathi data.

${ }^{7}$ We assume V-2 word order in Kashmiri to be an innovation in Indo-Aryan that occurred sometime after the Vedic period. The normal pattern in Kashmiri (and one held to be unique to it: see MASICA 1991: 336) appears to be geographically isolated. The other languages showing the V-2 pattern (Kishtawari, Shina of Gurez, Upper Poguli, Watali) are all spoken within or adjacent to the Kashmir Valley. 
One might ask if the Satzklammer in (32) is no more than an accidental or random occurrence in a full spectrum of variant word orders permitted by poetic licence. Or is it rather a statistically significant occurrence that identifies a specific alternative word order in some Indo-Aryan languages such as Hindi-Urdu (where it is limited to poetic discourse) but which has been generalized to all matrix clauses in Kashmiri? A perusal of Mir's corpus yielded no further instances of the V-2 order of (32) and most likely (32) is not a precursor of future changes in Hindi-Urdu word order.

F. Conclusion. The leftward position of lag- and a few other predicates governing infinitival complements is recurrent in Hindi-Urdu dialogue and demonstrably functions as a marker of a set of related attitudes. Even if only a stylistically marked feature, the presence of verb-left in Hindi-Urdu provides a plausible starting point for the emergence of non-clause-final word order for the verb that may be similar if not parallel to what occurred in earlier times in the Indo-Aryan languages of the Himalayas. ${ }^{8}$

\section{APPENDIX}

$<$ lagleft $>$ dataset from first fifty pages of Premchand's godān [Saraswati Press, 1970 edition].

1a. asnān-püjā kar-ne lagẽge to ... 7.9 [ = page 7, line 9]

1b. $\quad \tilde{a} \tilde{a} k h \tilde{o}$ se bhī kam sūjh-ne lag $\bar{a}$ thā 7.29

1c. lagte ho kos-ne 8.18

1d. havā mẽ garmī ā-ne lagī thī 9.7

1e. bholā par nashā carh-ne lagā 10.14

1f. $\quad$ šarāb pī-ne lagũ ũu, to ... 16.5

1g. aiyā̌š̄ kar-ne lagũũ, to phir kah-nā hī kyā 16.6

1h. aur horī ke mũh kī or tāk-ne lage. 16.10

1. magar vah pacrā sunā-ne lagũũ, to ... 17.8

1j. $\quad$ gobar kuch shānt ho gayā aur cup-cāp cal-ne lagā 19.11

$1 \mathrm{k}$ aur uchal-uchal-kar yah̄̄ rat lagā-ne laḡ̄ 9.36

11. $\quad \bar{u}$ par se lage bhunbhunā-ne 23.7

$1 \mathrm{~m}$. yā to calegī nahĩ̄, yā calegī to daur-ne lagegī 24.22

1n. $\quad$ rāh mẽ bātẽ ho-ne lagĩ 24.38

1. $\quad$ gobar ne baniye se loțā mããgā aur pānī khĩuc-ne lagā 25.34

1p. Iagtī pūch-ne, kiskī gāy hai? 29.3

1q. $\quad$ to phir naxre baghär-ne lage 29.8

1r. becāre pahar-rāt se kuțtī kāt-ne lagte 29.12

1s. gobar kāhe ko jag-ne lag $\bar{a} 29.35$

1t. $\quad$ sārā gãa ãv tāliyãa a pịt-ne lagega $\ldots 29.38$

1u. caudharī ... bããs kāt-ne lag $\mathbf{a} 31.15$

1v. $\quad$... sir, mũh, pīth par ãdhādhüdh jamā-ne lagī 32.7

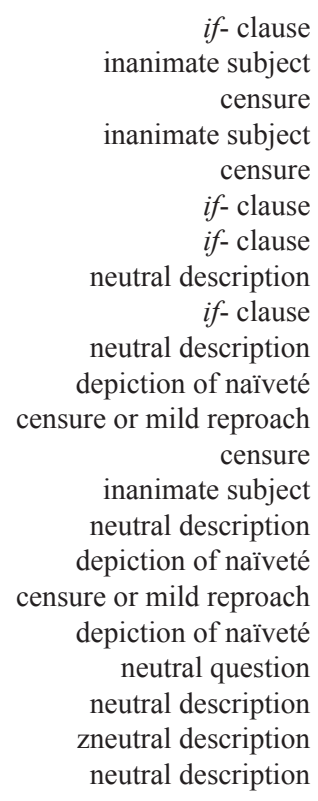

${ }^{8}$ In his recent three volume study on Himachali, Hendriksen reports on two intermediate cases: Kotgarhi and Kochi. While neither shows a regular V-2 pattern, they have evolved to the point at which main and subordinate clauses differ in word order and auxiliaries may separate from other parts of the verb:

a) hyunda bāssie jā gormi hoi (Kotgarhi) winter after GOES summer become

'After winter comes summer.'

(HENDRIKSEN 1986: 186)

He also reports that relative clauses in Kochi show a greater tendency to have the finite verbal element in clause-final position than do matrix clauses (1986: 188). This is another feature characteristic of Kashmiri V-2. See Hook \& Koul (1996). 
1w. caudharī qasmẽ khā-khākar apnī safāì de-ne lagāa 32.20

1x. aur ghasìt-tā huā alag le jā-kar lagā lātẽ jamā-ne 33.2

1y. $\quad$ hìrā ko udārtāpūrvak samjhāa-ne lagā 33.22

1z. ... aur prithvī kããp-ne lagtĩ hai. 34.30

2a. dhaniyā pati ko phațkär-ne lagī. 35.40

2b. ... aur ek cilam bharkar pī-ne lagāa. 37.23

2c. ... aur len-dār cārõ taraf se noc-ne lagte hã̃ 38.1

2d. horī jab kām-dhandhe se chutțī pākar cilam pine lagtā thā to ... 38.7

2e. dhaniyā aur horī donõ gāy bããdh-ne kā prabandh kar-ne lage. 38.29

2f. take kī naȳ̄ topī sir par rakh-kar jab ham akaṛ-ne lagte hã̃ 40.23

2g. zarā der ke lie kisī savārī par baiṭhkar jab ham ākāsh mẽ ur-ne lagte hãũ.

2h. rūpā ne ... kahāa-- ammãã kī, aur hãs-ne lagī 42.6

2i. horī bāhar khāt par baith-kar cilam pī-ne lagāa, to ... 43.3

$2 \mathrm{j}$. aur kal ko yahī gāy dūdh de-ne lagegī, to ... 43.9

$2 \mathrm{k} . \quad$ horì țithak gayā aur unkī bātẽ sun-ne lagāa. 43.19

21. aur vah jalā huā tambāk $\bar{u}$ pì-ne lag $\bar{a} 43.48$

$2 \mathrm{~m} \quad$ bailõ ke pās jākar unhẽ sahalā-ne lagāa, 44.6

$2 \mathrm{n}$. use apne āp par krodh $\bar{a}$-ne lagā 45.16

20. c cārõ or se hīrā par bauchār paṛ-ne laḡ 46.47

2p. horī ne dããațā -- phir kyõ bak-bak kar-ne lagī tū! 47.14

2q. $\quad$ gobar use cakit netrõ se dekh-ne lagā. 48.27

2r. $\quad s \bar{a} r a \bar{a} g \tilde{a} \tilde{a} v$ kããv-kããv kar-ne lagegā. 48.38

2s. $\quad$ merī chātī dhak-dhak kar-ne lagī. 50.30

2t. Iagā häth jor-ne, pairõ par-ne: 50.39

2u. ... aur 10-10 ke 5 not nikăl-kar mere hāthõ mẽ de-ne lagā 50.43

$2 \mathrm{v} . \quad$ sir pakar-kar baith gayā aur lagā hāy-hāy kar-ne. 51.2

2w. lag $\overline{\boldsymbol{a}}$ häth jor-ne. 51.12

$2 \mathrm{x} . \quad$ sir zamīn par ragar-kar kah-ne lagā: 51.14

2y. jahãa kō̄ javān sundar aurat dekhī aur bas lage ghür-ne, chātī pịt-ne 51.32

2z. $\quad$ lage aurõ kī tarah tum bhī cāplūsì kar-ne 51.37

neutral description censure

neutral description inanimate subject neutral description neutral description indefinite subject when-clause neutral description when-clause when-clause neutral description neutral description if- clause neutral description neutral description neutral description inanimate subject inanimate subject censure

neutral description neutral description inanimate subject mockery neutral description derision derision derision derision mockery

\section{REFERENCES}

\section{PRIMARY SOURCES}

Снатак Govind. 1976. ghāt (Murder). In: gār myațe ki gangā. A.B. Bahuguna, Ed. New Delhi: Alaknanda Prakashan. 120-125.

GhILDIYAL Durgaprasad. 1981. gāri (Pebbles). New Delhi: published by the author. godān. See Premchand.

KHATTRI Devakinandan. 1892. candrakāntā.

Mir Taqi Mir. 1941. kulliyāt. Abdul Bari Asi, Ed. Lucknow: Naval Kishor Press.

NeGI Mohanlal. 1967. joni par chäpu kilai? (Why are there spots on the moon?). Tihri: by author?

Premchand [alias Dhanpat Rai]. 1936. godān. (The Gift of a Cow). Allahabad: Saraswati Press. (Pagination from 1970 edition). Webtext at http://www-personal.umich.edu/ pehook/godan01.html

SHANT Ratan Lal. 1985. sāyikal (The bicycle). In Sheeraza 22, 2, 57-63.

\section{SECONDARY SOURCES}

Deshrande Madhav, Hook Peter E. (eds.). 2002. Indian Linguistic Studies: Festschrift in honour of George Cardona. Delhi: Motilal Banarsidass.

GamBHIR Vijay. 1981. Syntactic Restrictions and Discourse Functions of Word Order in Standard Hindi. University of Pennsylvani. PhD dissertation.

HendrIKSEn Hans. 1986. Himachali Studies III: Grammar. København: Munksgaard. 
Hook Peter E., Jain Kusum. 2002. "How to be Sarcastic in Hindi-Urdu." In: DeshPande \& Hook 2002: 365-373. Hook Peter E., Koul Omkar N. 1996. "Kashmiri as a V-2 Language.” In: Lakshmi \& MukherJee 1996: 95-105.

Lakshmi V.S., Mukherjee Aditi (eds.). 1996. Word Order in Indian Languages. Hyderabad: Centre of Advanced Study in Linguistics, Osmania.

Masica Colin P. 1976. Defining a Linguistic Area: South Asia. Chicago: Chicago University Press.

Masica Colin P. 1991. The Indo-Aryan Languages. Cambridge University Press.

McGregor R.S. 1993. The Oxford Hindi-English Dictionary. Delhi: Oxford University Press.

Ross John R. 1973. "The Penthouse Principle and the Order of Constituents." In: You Take the High Node and I'll

Take the Low Node: Papers from the Comparative Syntax Festival. Chicago: CLS, 397-422.

Russell Ralph, Islam Khurshidul. 1968. Three Mughal Poets. Cambridge: Harvard Univ Press. 